\title{
Korelasi Motivasi Belajar Terhadap Prestasi Belajar Siswa Kelas IV Di Madrasah Ibtidaiyah Muhammadiyah 04 Blimbing Paciran Suntari Daip
}

\section{Dosen Sekolah Tinggi Ilmu Tarbiyah Muhammadiyah Paciran Lamongan}

Email:Daip84@yahoo.co.id

Abstract: Learning is an activity that proceeds and is a very fundamental element in the implementation of each type and level of education. This means that the success or failure of the achievement of the educational objectives depends very much on the learning process that students experience when they are at school or in their home or family. Based on the background of the above problem, then the formulation of the problem as follows: What is the learning motivation of students of class X Subject PAI In SMKN 13 Malang and Is there a correlation of learning motivation with student achievement class X Subject PAI In SMKN 13 Malang. The method used in data collection is descriptive method. While the approach taken is a quantitative approach. Data collection in this study includes literature study and field study. The implementation of this field study involves observation techniques, interviews, and using data collection instruments in the form of questionnaires. Based on the results of correlation analysis obtained 0,538. In order for this number to be meaningful, it needs to be interpreted so as to give an explanation of the correlation between learning motivation and student achievement, that is by consulting through the value of $r$ on the product moment table, either with a significance level of 5\% or 1\%. For more details will be interpreted $r$ o and $r t$ (table) as follows. At the level of significance of $5 \%$ with the number of respondents $(N)=22$ obtained $r t=0.423$, while $r o=0.538$. Thus $r o$ is greater than $r$ or in other words $r$ o $>r$. This means indicating a significant or positive correlation between the two variables. At the level of significance of $1 \%$ with the number of respondents $(N)=22$ obtained $r t=0.537$, while $r o=$ 0.538. Thus $r$ o is greater than $r t$ or in other words $r o>r t$. This means indicating a significant or positive correlation between the two variables. So the hypothesis examined that "There is a significant correlation between learning motivation and learning achievement subjects PAI grade X students in SMKN 13 Malang also low.

Key word: Motivation to learn, Student Achievement

Manusia dalam hidup selalu melakukan kegiatan belajar. Manusia belajar sejak lahir dan dilakukan secara terus-menerus selama merasa itu hidup, karena manusia disamping sebagai makhluk biologis manusia juga merupakan makhluk sosial dan budaya yang selalu berusaha berkembang kearah lebih baik. Belajar adalah kegiatan yang berproses dan merupakan unsur yang sangat fundamental dalam penyelenggaraan setiap jenis dan jenjang pendidikan. Ini berarti, bahwa berhasil atau gagalnya pencapaian tujuan pendidikan itu amat bergantung pada proses belajar yang dialami siswa baik ketika ia berada di sekolah maupun di lingkungan rumah atau keluarganya sendiri. 
Belajar menurut Muhibbin Syah secara singkat diartikan sebagai suatu proses, belajar hampir selalu mendapat tempat yang luas dalam berbagai disiplin ilmu yang berkaitan dengan upaya kependidikan. Kerena demikian pentingnya arti belajar maka bagian terbesar upaya riset dan eksperimen psikologi belajar pun diarahkan pada tercapainya pemahaman yang lebih luas dan mendalam mengenai proses perubahan manusia itu. (Muhibbin Syah, 2009, p.63)

Belajar bukan merupakan tujuan, akan tetapi belajar adalah merupakan suatu proses yang dilakukan seseorang untuk mencapai tujuan dalam rangka memenuhi kebutuhan hidup tiap individu. Individu belajar adanya (stimulus) dari luar dan mungkin pola karena adanya dorongan dari dalam karena ada prinsipprinsip dinamisasi dalam diri individu. Adapun yang dimaksud dengan aspekaspek dinamisasi dalam individu ini adalah: Goal seeking, Mind, Drive, Goal seeking adalah; dimana tingkah laku individu terarah pada tujuan tertentu, sedangkan Mind adalah merupakan subtansi kualitatif yang berbeda dengan jasmani, adapun Drive adalah tenaga pendorong dari dalam diri individu dalam pengertian yang lebih luas sering disebut "Motive".

Menurut Skinner belajar adalah suatu prilaku. Pada saat orang belajar, maka responsnya menjadi lebih. Sebaliknya, bila ia tidak belajar maka responsnya menurun. (Dimyati-Mujiono, 2013, p.9) Sedangkan menurut Surya definisi belajar adalah suatu proses usaha yang dilakukan individu untuk memperoleh suatu perubahan tingkah laku yang baru keseluruhan, sebagai hasil pengalaman individu itu sendiri dalam interaksinya dengan lingkungan. Kesimpulan yang bisa diambil dari kedua pengertian di atas, bahwa pada prinsipnya, belajar adalah perubahan dari diri seseorang.(Surya, http://belajarpsikologi.com/pengertianbelajar-menurut-ahli/diakses tgl 14 Maret 2015)

Banyak faktor yang mempengaruhi proses belajar siswa, faktor-faktor dapat mendukung atapun menghambat porses belajar siswa. Semakin banyak faktor pendukung kegaiatan belajar, maka semakin besar kemungkinan terjadi perubahan tingkah laku yang diharapkan. Demikian juga sebaliknya semakin banyak faktor yang menghambat kegiatan belajar siswa maka akan semakin kecil kemungkinan terjadinya perubahan tingkah laku.

Faktor yang mempengaruhi proses belajar siswa bersumber dari dalam diri siswa maupun lingkungan. Faktor dari dalam diri siswa disebut faktor internal sedangkan faktor dari luar diri siswa biasa disebut dengan faktor eksternal. Faktor internal menjangkau seluruh pribadi siswa termasuk fisik dan mental. Faktor internal ini memiliki beberapa faktor yaitu faktor fisiologis yang bersifat jasmaniah ataupun diperoleh dari faktor psikologis yang bersifat rohaniah. Aspek fisiologis kondisi umum jasmani dan tonus (tegangan otot) yang menandai tingkat kebugaran organ-organ tubuh dan sendi-sendinya dapat mempengaruhi semangat dan intensitas siswa dalam mengikuti pelajaran. Sedangkan Aspek Psikologis banyak faktor yang termasuk aspek psikologis yang dapat mempengaruhi kuantitas dan kualitas perolehan pembelajaran siswa yang meliputi tingkat kecerdasan / intelegensi siswa, sikap siswa, bakat siswa, minat siswa, motivasi siswa. Faktor eksternal adalah faktor yang bersumber dari luar diri siswa yang bersangkutan. Faktor eksternal ini dibagi menjadi dua faktor yaitu faktor sosial dan faktor non-sosial. Faktor sosial adalah yang berhubungan dengan manusia, 
seperti para guru, para staf administrasi dan teman-teman sekelas dapat mempengaruhi semangat belajar seorang siswa. Faktor non-sosial adalah gedung sekolah dan letaknya, rumah tempat tinggal keluarga siswa dan letaknya, alat-alat belajar, keadaan cuaca dan waktu belajar yang digunakan siswa. Faktor-faktor ini dipandang turut menentukan tingkat keberhasilan belajar siswa. (Muhibbin Syah, 2009, p.146-155)

Semua faktor di atas secara bersama-sama akan mempengaruhi proses dari belajar siswa. Tetapi motivasi yang merupakan faktor yang penting dari individu yang mempengaruhi proses dari hasil belajar.

Semakin baik dan semakin lengkap fasilitas yang di miliki sekolah maka siswa akan berpengaruh terhadap motivasi siswa yang pada akhirnya berpengaruh juga terhadap prestasi siswa.

Menurut Hamzah B. Uno motivasi adalah dorongan dasar yang menggerakkan seseorang bertingkah laku. Dorongan ini berada pada diri seseorang yang menggerakkan untuk melakukan sesuatu yang sesuai dengan dorongan dalam dirinya. Oleh karena itu, perbuatan seseorang yang didasarkan atas motivasi tertentu mengandung tema sesuai dengan motivasi yang mendasarinya. (Hamzah. B. Uno, 2014, p.1)

Sedangkan menurut Mustaqim pengertian motivasi adalah perubahan energi dari dalam pribadi seseorang yang ditandai dengan timbulnya perasaan dan reaksi untuk mencapai tujuan. Perubahan energi di dalam pribadi seseorang itu berbentuk suatu aktivitas nyata berupa kegiatan fisik. Seseorang yang mempunyai tujuan tertentu dalam motivasinya, maka ia mempunyai motivasi yang kuat untuk mencapai tujuan tersebut dengan segala upaya yang dapat ia lakukan. (Mustaqim, http://expresisastra.blogspot.com/2013/12/pengertian-dan-definisi

motivasi.html/diakses tgl 15 Maret 2015)

Pada umunya motivasi tidak akan timbul begitu saja, tapi motivasi akan bangkit bila ada minat yang besar, proses pembelajaran akan dapat berhasil dengan baik apabila semua siswa mempunyai minat yang besar dalam mengikuti proses pembelajaran tersebut.

Dengan memperhatikan latar belakang di atas, maka penulis tertarik untuk mengkaji motivasi belajar terhadap prestasi belajar siswa. maka penulis ingin mengkajinya dengan judul penelitian "Korelasi Motivasi Belajar Terhadap Prestasi Belajar Siswa Kelas X Mata Pelajaran PAI Di SMKN 13 Malang”

Berdasarkan latar belakang masalah diatas, maka rumusan rumusan masalah sebagai berikut: Bagaimanakah motivasi belajar siswa kelas X Mata Pelajaran PAI Di SMKN 13 Malang dan Apakah ada korelasi motivasi belajar dengan prestasi belajar siswa kelas X Mata Pelajaran PAI Di SMKN 13 Malang?

\section{Kajian Teori}

\section{Pengertian Motivasi}

Purwanto menjelaskan bahwa motivasi diartikan dorongan psikologis yang mengarahkan seseorang ke arah suatu tujuan. Motivasi ialah suatu proses untuk menggalakkan sesuatu tingkah laku supaya dapat mencapai matlumat-matlumat tertentu. (Purwanto, https://addinalhadi.wordpress.com/2012/11/07/motif-danmotivasi/diakses tgl 01 April 2015) 
Sedangkan Oemar Hamalik berpendapat bahwa istilah motivasi menunjuk kepada semua gejala yang terkandung dalam stimulasi tindakan ke arah tujuan tertentu dimana sebelumnya tidak ada gerakan menuju ke arah tertentu. (Oemar Hamalik, 2010, p.173)

Dari beberapa pengertian motivasi di atas dapat diambil kesimpulan bahwa yang dimaksud dengan motivasi adalah keseluruhan daya penggerak yang terdapat di dalam diri seseorang yang menimbulkan kegiatan dan memberikan arahan pada kegiatan tersebut untuk mencapai tujuan.

Dalam proses belajar motivasi sangat diperlukan, sebab seseorang yang tidak mempunyai motivasi dalam belajar tidak mungkin melakukan aktivitas belajar. (Haryu Islamuddin, 2012, p.259) Dalam pengertian yang luas, motivasi belajar merupakan kondisi psikologis yang mendorong seseorang untuk belajar. (Muhibbin Syah, 2009, p.131) Anak yang mempunyai motivasi belajar cenderung menghargai dan menikmati belajar dengan senang hati. Mereka seakan-akan mempunyai prinsip belajar sepanjang hidup, selalu tertarik untuk menambah wawasan pengetahuan dengan berbagai cara. Mereka memiliki bakat alami untuk melakukan hal tersebut, karena rasa ingin tahu terhadap segala sesuatu di sekitarnya sangat besar.

Motivasi belajar adalah dorongan internal dan eksternal pada siswa-siswi yang sedang belajar untuk mengadakan perubahan tingkah laku, pada umumnya dengan beberapa indicator atau unsur yang mendukung. (Hamzah. B. Uno, 2014, p.23) Peserta didik akan melakukan suatu proses belajar betapapun beratnya jika ia mempunyai motivasi yang tinggi. Motivasi belajar sangat penting untuk mengembangkan potensi-potensi yang terdapat pada diri peserta didik dalam bidang-bidang tertentu. Mempunyai motivasi diri dan keinginan untuk belajar merupakan permasalahan kritis bagi keberhasilan anak-anak di masa depan.

\section{Jenis-jenis motivasi}

Motivasi dapat dibedakan menjadi dua macam yaitu : motivasi intrinsik dan motivasi ekstrinsik.

Motivasi Instrinsik

Motivasi intrinsik adalah motif-motif yang menjadi aktif atau berfungsinya tidak perlu dirangsang dari luar, karena dalam diri setiap individu sudah ada dorongan untuk melakukan sesuatu.(Haryu Islamuddin, 2012, p.260) Hamzah B Uno juga menjelaskan bahwa motivasi belajar dapat timbul karena faktor intrinsik berupa hasrat dan keinginan berhasil, dorongan kebutuhan belajar dan harapan akan cita-cita.(Hamzah. B. Uno, 2014, p.23)

Pada motivasi intrinsik, anak belajar karena belajar itu sendiri cukup bermakna baginya, tujuan yang lain dicapai terletak dalam perbuatan belajar itu sendiri. Misalnya, siswa belajar karena ingin mengetahui seluk beluk suatu masalah selengkap-lengkapnya, ingin menjadi orang yang terdidik atau ingin menjadi ahli bidang studi tertentu dan sebagainya. Keinginan itu hanya dapat dipenuhi dengan belajar giat, tidak ada cara lain untuk menjadi orang terdidik atau ahli selain belajar. 
Motivasi intrinsik termasuk dalam dorongan kognitif yang merupakan kebutuhan untuk mengetahui, mengerti dan memecahkan suatu masalah yang timbul di dalam proses interaksi antara peserta didik dengan tugas, masalah atau lingkungan.

Motivasi Ekstrinsik

Motivasi ekstrinsik adalah motif-motif yang aktif dan berfungsi karena adanya perangsang dari luar.(Haryu Islamuddin, 2012, p.262) Hamzah B Uno juga menjelaskan, motivasi ekstrinsik adalah adanya penghargaan lingkungan belajar yang kondusif dan kegiatan belajar yang menarik.(Hamzah. B. Uno, 2014, p.23)

Peserta didik yang terdorong untuk belajar karena pengaruh rangsangan dari luar berusaha menjadi pandai dengan tujuan mencari ketenaran yang berhubungan erat dengan kebutuhan dan penghargaan. Dalam hal ini peserta didik berusaha mencapai hasil yang sebaik-baiknya di sekolah untuk mengesankan orang lain, mendapat perhatian yang menyenangkan, untuk dikenang dengan baik oleh orang lain. Peserta didik tekun belajar, melaksanakan tugas-tugas bukan karena untuk memperoleh pengetahuan atau kecakapan, melainkan untuk memperoleh status dan harga diri.

Pada motivasi ekstrinsik, anak belajar bukan karena belajar itu penting baginya, melainkan mengharapkan sesuatu di balik belajar itu. Tujuan yang ingin dicapai terletak di luar perbuatan belajar. Misalnya siswa rajin belajar untuk memperoleh hadiah, menghindari hukuman dan sebagainya. Pada motivasi belajar ekstrinsik, dorongan belajar bersumber dari suatu kebutuhan, tetapi kebutuhan itu sebenarnya juga dapat dipenuhi melalui kegiatan selain belajar.

Berdasarkan uraian di atas dapat disimpulkan bahwa motivasi ada 2 (dua) jenis, yaitu : motivasi instrinsik dan motivasi ekstrinsik. Motivasi instrinsik adalah motivasi yang berasal dari dalam diri seseorang, sedangkan motivasi ekstrinsik adalah motivasi yang berasal dari luar dirinya.

\section{Cara-cara Membangkitkan Motivasi}

Membangkitkan motivasi bukanlah pekerjaan yang mudah. Untuk itu guru perlu mengenal peserta didik dan mempunyai kesanggupan kreatif untuk menghubungkan pelajaran dan minat peserta didik.

Ada beberapa bentuk dan cara untuk membangkitkan motivasi belajar peserta didik di sekolah antara lain:

Penghargaan

Dengan diberikan penghargaan pada sebuah prestasi untuk dicapai peserta didik, maka akan menimbulkan motivasi tersendiri bagi peserta didik. Karena peserta didik akan merasa bahwa kerja yang dilakukan dalam belajar mendapatkan sebuah penghargaan. (Oemar Hamalik, 2010, p.184)

Pemberian angka

Pemberian angka yang baik bagi peserta didik merupakan motivasi yang kuat. Umumnya setiap peserta didik ingin mengetahui hasil 
pekerjaannya, yakni berupa angka yang diberikan oleh guru. Peserta didik yang mendapat angkanya baik akan mendorong motivasi belajarnya menjadi lebih besar, sebaliknya peserta didik yang mendapat angka kurang baik mungkin menimbulkan frustasi atau dapat juga menjadi pendorong agar belajar lebih baik. Namun demikian angka itu harus benar-benar menggambarkan hasil belajar peserta didik. Dengan demikian angka bukan semata-mata tujuan dari belajar itu sendiri. Karena belajar semata-mata untuk mencapai angka tidak akan memberi hasil belajar yang sejati.

Keberhasilan dan tingkat aspirasi

Tingkat aspirasi menunjukkan kepada tingkat pekerjaan yang diharapkan pada masa depan berdasarkan keberhasilan atau kegagalan dalam tugas-tugas yang mendahuluinya. Konsep ini berkaitan erat dengan konsep seseorang tentang dirinya dan kekuatan-kekuatannya.

Pemberian pujian

Pemberian pujian kepada peserta didik atas hal-hal yang telah dilakukan dengan berhasil besar manfaatnya sebagai pendorong belajar. Pujian menimbulkan rasa puas dan senang. Pujian diberikan sesuai dengan hasil kerja, bukan dibuat-buat atau bertentangan dengan hasil kerja anak didik.

Kompetisi

Kompetisi baik individual maupun kelompok dapat mempertinggi hasil belajar. Karena peserta didik terdorong untuk menjadi yang terbaik dan mengalahkan peserta didik yang lain Sehingga dapat mengangkat harga dirinya di hadapan teman-temannya.

Pemberian harapan

Harapan selalu mengacu ke depan. Artinya, jika seseorang berhasil melaksanakan tugasnya atau berhasil dalam kegiatan belajarnya, dia dapat memperoleh dan mencapai harapan-harapan yang telah diberikan kepadanya sebelumnya. Itu sebabnya pemberian harapan kepada siswa dapat menggugah minat dan motivasi belajar. (Oemar Hamalik, 2010, p.184-186)

Dari uraian di atas, menurut penulis hal yang perlu diperhatikan adalah bahwa sebaiknya motivasi belajar itu ditimbulkan dan dikembangkan dengan kesadaran sendiri tanpa tergantung pada faktor-faktor luar. Jika motivasi belajar tergantung pada faktor luar, seperti dorongan dari guru, orang tua atau pacar, biasanya motivasi tersebut cenderung tidak stabil dan mudah menjadi lemah. Namun demikian, bukan berarti faktor-faktor dari luar itu tidak atau kurang bermanfaat. Guru misalkan, guru dalam hal ini sangat berperan sekali dalam mengembangkan dan mengarahkan peserta didik agar motivasi belajar yang ada dalam diri peserta didik dapat berkembang secara optimal, sehingga mencapai hasil yang baik. 


\section{Fungsi Motivasi}

Menurut Sardiman fungsi motivasi belajar ada tiga yakni sebagai berikut :

1) Mendorong manusia untuk berbuat: Sebagai penggerak atau motor yang melepaskan energi.

2) Menentukan arah perbuatan : Yakni ke arah tujuan yang hendak dicapai.

3) Menyeleksi perbuatan : Yakni menentukan perbuatan-perbuatan apa yang harus di jalankan yang serasi guna mencapai tujuan itu, dengan menyampingkan perbuatan yang tidak bermanfaat dengan tujuan itu. (Nasution, 1995, p.76)

Berdasarkan hal tersebut penulis dapat menyimpulkan bahwa motivasi berfungsi sebagai pendorong, pengarah dan penggerak dalam melakukan sesuatu untuk mencapai tujuan. Dengan adanya motivasi yang baik dalam kegiatan belajar akan dapat menunjukkan hasil yang baik pula.

\section{Pengertian Prestasi Belajar}

Menurut WJS Poerwadarminta berpendapat, bahwa prestasi adalah hasil yang telah dicapai (dilakukan, dikerjakan dan sebagainya). (WJS Poerwadarminta, 1982, p.773) Sedangkan menurut Mas'ud Khasan Abdul Qahar, prestasi adalah apa yang telah dapat diciptakan, hasil pekerjaan, hasil yang menyenangkan hati yang diperoleh dengan jalan keuletan bekerja.(Syaiful Bahri Djamarah, 1994, p. 21) Sedangkan menurut Bloom prestasi belajar adalah proses belajar yang dialami siswa dan menghasilkan perubahan dalam bidang pengetahuan, pemahaman, penerapan, daya analisis, sintesis dan evaluasi.(Reni Kbar Hawadi, 2004, p.68)

Dari beberapa pengertian prestasi yang dikemukakan para ahli di atas, jelas terlihat perbedaan pada kata-kata tertentu sebagai penekanan, namun intinya sama, yakni hasil yang dicapai dari suatu kegiatan. Untuk itu dapat difahami bahwa prestasi adalah hasil dari suatu kegiatan yang telah dikerjakan, diciptakan, yang menyenangkan hati yang diperoleh dengan jalan keuletan kerja, baik secara individual maupun kelompok dalam bidang kegiatan tertentu.

Jadi prestasi belajar adalah hasil yang diperoleh berupa kesan-kesan yang mengakibatkan perubahan dalam diri individu maupun kelompok sebagai hasil dari aktifitas dalam belajar.

Surya menyatakan bahwa pengertian dari belajar adalah suatu proses yang dilakukan individu untuk memperoleh suatu perubahan tingkah laku yang baru secara keseluruhan, sebagai hasil dari pengalaman individu itu sendiri dalam interaksi dengan lingkungannya.( Tohirin, 2005, p.8) Dan dalam bukunya ANITA WOOLFOLK menjelaskan bahwa learning is process through which experience causes permanent change in knowledge or behavior.( Anita Woolfolk, 2004, p.198)

Secara umum belajar dapat diartikan sebagai suatu perubahan tingkah laku yang relatif menetap terjadi sebagai hasil dari pengalaman atau tingkah laku. Yang dimaksud dengan pengalaman adalah segala kejadian yang secara sengaja dialami oleh setiap orang. Sedangkan latihan merupakan kejadian yang dengan sengaja dilakukan setiap orang secara berulang-ulang. (Muhaimin, Abd Ghofir, Nur Ali Rahman, 1996, p.43) 


\section{Macam-macam Prestasi Belajar}

Adapun macam-macam prestasi belajar antara lain;

a. Prestasi yang bersifat kognitif

Yang termasuk dalam prestasi yang bersifat kognitif yaitu; ingatan, pemahaman, penerapan, pengamatan, analisis, sintesis dan lain-lain. Misalnya seorang siswa mampu menyebutkan materi pelajaran yang sudah dipelajari pada minggu lalu maka siswa tersebut bisa dikatakan potensi dalam kognitifnya dan lain sebagainya.

b. Prestasi yang bersifat afektif

Yang termasuk dalam prestasi afektif adalah yaitu sikap menghargai, penerimaan, penolakan dan lain-lain. Misalnya seorang siswa dapat menunjukkan sikap menerima dan menolak terhadap sustu pernyataan atau suatu permasalahan dan lain-lain. Itu bisa dikatakan bahwa siswa mengalami prestasi afektif.

c. Prestasi yang bersifat psikomotorik

Yang termasuk prestasi yang bersifat psikomorik siswa yaitu; kecakapan ekspresi verbal dan non verbal, ketrampilan bergerak dan bertindak. Misalnya seorang siswa menerima tentang adab sopan santun kepada orangtua, maka si anak mengaplikasikan pelajaran tersebut ke dalam kehidupan sehari-hari. (Muhibbin Syah, 2006, p.154)

\section{Faktor-faktor yang Mempengaruhi Prestasi Belajar}

Faktor-faktor psikologis yang mempengaruhi belajar, termasuk kedalam faktor internal, yakni faktor dari diri dalam siswa. Faktor ini terdiri dari dua aspek antara lain:

Aspek Fisiologis

Aspek fisiologis yang mempengaruhi belajar berkenaan dengan keadaan dengan keadaan dan kondisi umum jasmani seseorang, misalnya menyangkut kesehatan atau kondisi tubuh, seperti sakit atau terjadinya gangguan pada fungsi-fungsi tubuh. Aspek ini juga menyangkut kebugaran tubuh. Tubuh yang kurang prima, akan mengalami kesulitan belajar. Untuk menjaga kondisi tubuh, dianjurkan untuk menjaga atau mengatur pola istirahat yang baik dan mengatur menu makanan atau mengonsumsi makanan yang sehat dan bergizi. (Muhibbin Syah, 2006, p.127)

Aspek Psikologis

Proses belajar merupakan hal yang kompleks. Siswalah yang menentukan terjadi dan tidak terjadinya belajar. Untuk bertindak belajar siswa menghadapi masalah-masalah secara intern. Jika siswa tidak dapat mengatasi masalahnya, maka ia tidak belajar dengan baik. (Dimyati, Mudjiono, 1997, p.238)

Faktor eksternal siswa juga terdiri atas tiga macam yakni:

Lingkungan sosial

Lingkungan sosial sekolah seperti para guru, para staf administrasi dan teman-teman sekelas dapat mempengaruhi semangat belajar seorang siswa. Para guru yang selalu menunjukkan sikap dari prilaku yang simpatik dan memperlihatkan suri teladan yang baik dan rajin khususnya dalam hal belajar, misalnya rajin belajar dan berdiskusi, dapat menjadi 
daya dorong yang positif bagi kegiatan belajar siswa.( Dimyati, Mudjiono, 1997, p.137)

Lingkungan non-sosial

Faktor-faktor yang termasuk lingkungan non-sosial ialah gedung sekolah dan letaknya, rumah tempat tinggal keluarga siswa dan letaknya, alat-alat belajar, keadaan cuaca dan waktu belajar yang digunakan siswa. Factor-faktor ini turut menentukan tingkat keberhasilan belajar siswa. (Dimyati, Mudjiono, 1997, p.138)

Pendekatan belajar siswa.

Faktor pendekatan belajar adalah upaya belajar siswa yang meliputi strategi dan metode yang digunakan siswa untuk melakukan kegiatan pembelajaran materi-materi pelajaran. (Dimyati, Mudjiono, 1997, p.133)

\section{Metode Penelitian \\ Rancangan Penelitian}

Penelitian ini merupakan penelitian kuantitatif deskriptif korelasional, dimana penelitian kuantitatif adalah suatu proses menemukan pengetahuan yang menggunakan data berupa angka sebagai alat menemukan keterangan mengenai apa yang ingin diketahui peneliti. Angka-angka yang terkumpul sebagai hasil penelitian kemudian dapat dianalisis menggunakan metode statistik. (Margono, 2000, p.103) Sedangkan jenis penelitiannya berupa korelasi yang bertujuan untuk menemukan ada tidaknya hubungan antara dua variabel, dan apabila ada seberapa erat hubungannya. (Suharsimi Arikunto, 2005, p.247)

\section{Variabel Penelitian}

Dalam penelitian kuantitatif, variabel mempunya ciri-ciri tertentu. Menurut purwanto variabel mempunyai tiga ciri, yaitu: dapat diukur, membedakan satu objek dari objek yang lain dalam satu populasi, dan nilainya bervariasi. (Purwanto, 2007, p.45) Djunaidi juga mengatakan bahwa dalam penelitian pendidikan hubungan antara variabel adalah bersifat multivariate, dengan kata lain hubungan deterministis antara satu variabel bebas dengan satu variabel lain yang tidak bebas ada dan selalu terjadi. (Djunaidi Ghoni, 2009, p.119) Maka dapat ditentukan beberapa variabel sebagai berikut:

1. Variabel bebas (independent variable) atau variabel $\mathrm{X}$ adalah variabel yang dipandang sebagai penyebab munculnya variabel terikat yang diduga sebagai akibatnya.

2. Variabel terikat (dependent variable) atau variabel $\mathrm{Y}$ adalah variabel (akibat) yang dipradugakan, yang bervariasi mengikuti perubahan dari variabel-variabel bebas. Umumnya merupakan kondisi yang ingin kita ungkap dan jelaskan.

Adapun variabel yang hendak diteliti adalah:

1. Variabel bebas (X) : Motivasi Belajar

2. Variabel terikat $(\mathrm{Y}) \quad$ : Prestasi belajar siswa

\section{Populasi dan Sampel}

Diantara langkah awal dalam penelitian ini adalah dengan menentukan:

Populasi

Menurut Suharsimi Arikunto, populasi adalah keseluruhan subyek penelitian apabila seseorang ingin meneliti semua subyek, maka penelitian 
tersebut merupakan penelitian populasi. Sedangkan menurut Bambang Soepono populasi adalah keseluruhan subyek/obyek yang menjadi sasaran penelitian. Dan menurut Ibnu Hajar, populasi adalah kelompok besar individu yang mempunyai karakteristik umum sama.

Dari para pendapat diatas dapat disimpulkan bahwa populasi adalah keseluruhan subyek obyek yang memiliki karakteristik umum sama. Adapun yang menjadi populasi dalam penelitian ini adalah siswa kelas $\mathrm{X}$ mata pelajaran PAI di SMKN 13 Malang yang berjumlah 40 siswa.

Sampel

Menurut Suharsimi Arikunto sampel adalah sebagian atau wakil populasi yang diteliti. Sedangkan menurut Bambang Soepono sampel adalah bagian populasi yang masih terwarnai oleh sifat dan karakteristik populasi untuk dikenakan penelitian ini.

Menurut Soemanto sampel adalah sebagian subyek yang dipilih dan dianggap mewakili keseluruhan populasi. Dalam pengambilan sampel, peneliti menggunakan teknik Non random yang jenisnya Purposive Sample (sample bertujuan), yaitu sampel yang dilakukan dengan cara mengambil subyek bukan strata, random ataupun daerah tetapi didasarkan atas tujuan tertentu.

Dalam pengambilan sample menggunakan Purposive Sample ada beberapa syarat-syarat yang harus dipenuhi, yaitu:

a. Pengambilan sampel harus didasarkan atas ciri-ciri, sifat-sifat atau karakteristik tertentu, yang merupakan ciri-ciri pokok populasi.

b. Subyek yang diambil sebagai sampel benar-benar merupakan subyek yang paling banyak mengandung ciri-ciri yang terdapat pada populasi (key subjectis)

c. Penentuan karakteristik populasi dilakukan dengan cermat didalam study pendahuluan.

\section{Metode Pengumpulan Data}

Dalam hal ini metode pengumpulan data yang digunakan adalah metode:

Metode Interview

Interview adalah metode pengumpulan data dengan jalan Tanya jawab atau wawancara antara peneliti dengan responden untuk memperoleh informasi. Teknik ini dilakukan secara tatap muka. Interview digunakan untuk mengumpulkan data tentang sejarah atau latar belakang berdirinya lembaga serta hal-hal yang kurang jelas dari jawaban angket, sehingga perlu ditanyakan kembali kepada gurunya sebagai pembimbing secara langsung. Wawancara nantinya akan diberikan kepada kepala sekolah, guru dan beberapa siswa.

Metode angket

Angket atau questioner adalah metode pengumpulan data melalui sejumlah pertanyaan tertulis yang dipergunakan untuk memperoleh informasi dari responden dalam arti laporan tentang pribadinya, hal-hal yang ia ketahui.

Dalam pelaksanaan penelitian ini dengan membuat daftar pertanyaan yang diberikan kepada respondent disertai alternative jawaban. Dan angket 
nantinya diajukan kepada siswa untuk memperoleh data tentang Pengaruh Kompetensi Paedagogik Guru dan prestasi belajar siswa.

Metode Dokumentasi

Dokumentasi adalah cara pengumpulan data mengenai hal-hal berupa benda-benda tertulis seperti buku-buku, majalah, dokumen, peraturanperaturan notulen rapat, catatan harian, dan sebagainya. Dokumentasi dalam penelitian ini nantinya ditujukan untuk memperoleh data langsung dari tempat penelitian, yang meliputi struktur organisasi, jumlah guru dan karyawan, jumlah siswa, dan segala sesuatu yang mendukung penelitian.

Teknik Analisis Data

Data-data yang sudah ada (terkumpul), sebelum dianalisis, terlebih dahulu dilakukan pengolahan data. Pengolahan data melalui proses sebagai berikut:

Editing (penyuntingan), yaitu dengan memeriksa seluruh daftar pertanyaan yang dikembangkan respondent.

Koding (pengkodean), yaitu memberi tanda (simbol) yang berupa angket pada jawaban respondent yang diterima.

Tabuling (tabulasi) yaitu menyusun dan menghitung data hasil pengkodean untuk disajikan dalam bentuk tabel.

Setelah pengolahan data lalu dilakukan analisa data untuk membuktikan efektif tidaknya Korelasi Motivasi Belajar Terhadap Prestasi Belajar Siswa Kelas X Mata Pelajaran PAI Di SMKN 13 Malang sesuai dengan jenis data pada variabel tersebut, maka penulis menggunakan teknik analisis data sebagai berikut:

Teknik analisa prosentase

Semua data-data yang berhasil dikumpulkan dari sumber-sumber penelitian akan dibahas oleh penulis dengan menggunakan metode deskriptif analisis, ya itu menjelaskan data-data yang diperolehnya dengan menggunakan perhitungan prosentase atau biasa disebut frekuensi relative.

Untuk memperoleh frekuensi relative digunakan rumus:

$\mathrm{P}=\mathrm{F} / \mathrm{N} \times 100 \%$

Keterangan :

$\mathrm{F} \quad=$ Frekuensi yang sedang dicari prosentasenya.

$\mathrm{N} \quad=$ Number of cases (jumlah frekuensi atau banyaknya individu)

$\mathrm{P} \quad=$ Angket prosentase.

Adapun untuk memberikan nilai pada angket, penulis memberikan ketentuan sebagai berikut:

Untuk score jawaban SS (sangat setuju) dinilai 4

Untuk score jawaban S (setuju) dinilai 3

Untuk score jawaban TS (tidak setuju) dinilai 2

Untuk score jawaban STS (sangat tidak setuju) dinilai 1

Dan untuk menafsirkan hasil perhitungan dengan prosentase penelitian sebagai berikut:

$65 \%-100 \%=$ tergolong baik

$35 \%-65 \%=$ tergolong cukup

$20 \%-35 \%=$ tergolong kurang 
Kurang dari $20 \%=$ tergolong tidak baik

Untuk mengetahui efektif dan tidaknya Korelasi Motivasi Belajar Terhadap Prestasi Belajar Siswa Kelas X Mata Pelajaran PAI Di SMKN 13 Malang maka penulis menggunakan rumus "uji $\mathrm{t}$ " yaitu:

Teknik Analisa uji t (Test "T")

a. Mencari mean variabel $\mathrm{X}$, dengan rumus:

$$
\mathrm{Mx}=\frac{\sum x}{N_{x}}
$$

b. Mencari mean variabel $\mathrm{Y}$, dengan rumus:

$$
\mathrm{My}=\frac{\sum y}{N_{y}}
$$

c. Mencari deviasi standar Variabel $\mathrm{X}$ dengan rumus:

$$
x=\mathrm{X}-\mathrm{M} x
$$

d. Mencari deviasi standar Variabel $\mathrm{Y}$ dengan rumus:

$$
y=\mathrm{Y}-\mathrm{My}
$$

jumlah $x$ atau $\sum x$ harus sama dengan nol.

a.Menguadratkan $x$ lalu dijumlahkan; diperoleh $\sum x_{2}$

b.Menguadratkan $y$ lalu dijumlahkan; diperoleh $\sum y 2$

c.Mencari

$$
t_{0}=\frac{M x-M y}{\sqrt{\frac{\left(\sum x^{2}+\sum y^{2}\right)}{\left(N_{x}+N_{y}\right)} \frac{\left(N_{1}+N_{2}\right)}{\left(N_{1} \cdot N_{2}\right)}}}
$$

\section{Paparan Dan Pembahasan Data Hasil Penelitian Pengujian Hipotesis}

Analisis pendahuluan

Pengujian hipotesis dimaksudkan untuk mengolah data yang telah terkumpul baik dari data variabel motivasi belajar (X) maupun dari variabel prestasi belajar (Y) yang bertujuan untuk membuktikan diterima atau tidaknya hipotesis yang diteliti. Untuk memudahkan pengolahan data, maka perlu dibuat tabel kerja sebagaimana dalam tabel berikut ini.

Dengan melihat tabel kerja diatas, dapat diketahui :

$$
\begin{aligned}
& \sum x=1.804 \\
& \sum y=1.853 \\
& \sum x_{2}=148.514
\end{aligned}
$$

$$
\begin{aligned}
& \sum y_{2}=157.199 \\
& \sum x y=152.383 \\
& \sum N=22
\end{aligned}
$$

Analisis uji hipotesis

Setelah diketahui tabel kerja koefisien korelasi antara variabel $\mathrm{X}$ dan variabel $\mathrm{Y}$, selanjutnya data tersebut dimasukkan ke dalam rumus korelasi product moment sebagai berikut.

$$
=\frac{N \sum x y-\left(\sum x\right)\left(\sum y\right)}{\boldsymbol{r}_{\boldsymbol{x} y}}
$$




$$
\begin{aligned}
= & \frac{22(152.383)-(1.804)(1.853)}{\sqrt{\left\{22(148.514)-(1.804)^{2}\right\}\left\{22(157.199)-(1853)^{2}\right\}}} \\
& =\frac{3.352 .426-3.342 .812}{\sqrt{(3.267 .308-3.254 .416)(3.458 .378-3.433 .209)}} \\
& =\frac{9.614}{\sqrt{(12.892)(24.769)}} \\
\boldsymbol{r}_{\boldsymbol{x} y} & =\frac{9.614}{\sqrt{319.321 .948}} \\
\boldsymbol{r}_{\boldsymbol{x} y} & =\frac{9.614}{17.869,58164} \\
\boldsymbol{r}_{\boldsymbol{x} y} & \\
\boldsymbol{r}_{\boldsymbol{x} y} & =0,53800923792 \text { dibulatkan menjadi } 0,538
\end{aligned}
$$

Berdasarkan perhitungan di atas, diketahui bahwa hasil dari koefisien korelasi antara variabel motivasi belajar dan prestasi belajar siswa $\boldsymbol{r}_{\boldsymbol{x} y}=$ 0,538 .

\section{Pembahasan Hasil Penelitian}

Dalam pembahasan ini penulis akan mendeskripsikan hasil penelitian untuk mengetahui signifikansi hasil penelitian. Berdasarkan hasil analisis korelasi diperoleh angka 0,538. Agar angka ini bisa berarti, maka perlu diinterpretasikan sehingga memberi penjelasan tentang korelasi antara motivasi belajar dengan prestasi belajar siswa, yaitu dengan mengkonsultasikannya melalui nilai $r$ pada tabel product moment, baik dengan taraf signifikansi $5 \%$ maupun $1 \%$. Untuk lebih jelasnya akan diinterprestasikan ro dan $\mathrm{r}$ t (tabel) sebagai berikut.

Taraf Signifikansi $5 \%$

Pada taraf signifikansi $5 \%$ dengan jumlah responden $(\mathrm{N})=22$ diperoleh $\mathrm{r} t=0,423$, sedang $\mathrm{r}$ o $=0,538$. Dengan demikian r o lebih besar dari $\mathrm{r}$ t atau dengan kata lain $\mathrm{r}$ o $>\mathrm{rt}$. Hal ini berarti menunjukkan signifikansi atau adanya korelasi yang positif antara kedua variabel tersebut.

Taraf Signifikansi $1 \%$

Pada taraf signifikansi $1 \%$ dengan jumlah responden $(\mathrm{N})=22$ diperoleh $\mathrm{rt}=0,537$, sedang $\mathrm{r} \mathrm{o}=0,538$. Dengan demikian $\mathrm{r}$ o lebih besar dari $\mathrm{rt}$ atau dengan kata lain $\mathrm{ro}>\mathrm{r}$. Hal ini berarti menunjukkan signifikansi atau adanya korelasi yang positif antara kedua variabel tersebut.

Berdasarkan perhitungan nilai antara variabel X (Motivasi Belajar) dengan variabel Y (Prestasi Belajar Mata Pelajaran PAI) diperoleh hasil yang signifikan, artinya ada korelasi yang signifikan antara motivasi belajar dengan prestasi belajar mata pelajaran PAI. Jadi hipotesis yang diteliti bahwa 
"Ada korelasi yang signifikan antara motivasi belajar dengan prestasi belajar mata pelajaran PAI siswa kelas X di SMKN 13 Malang rendah juga.

\section{Kesimpulan dan Saran \\ Simpulan}

Berdasarkan hasil penelitian penulis terhadap Korelasi Motivasi Belajar Terhadap Prestasi Belajar Siswa Kelas X Mata Pelajaran PAI Di SMKN 13 Malang kepada 24 siswa sebagai responden, dapat diangkat suatu kesimpulan sebagai berikut:

1. Motivasi belajar peserta didik kelas X Mata Pelajaran PAI Di SMKN 13 Malang adalah baik. Hal ini berdasarkan pada hasil penelitian yang dilakukan, di mana nilai rata-rata yang diperoleh melalui jawaban responden adalah 82,18 yang berada pada interval $82-85$.

2. Dari hasil analisis kuantitatif menunjukkan bahwa motivasi mempunyai korelasi terhadap prestasi belajar kelas X Mata Pelajaran PAI Di SMKN 13 Malang. Hal tersebut dibuktikan dengan hasil koefisien korelasi product moment yang didapat 0,538 yang lebih besar dari korelasi yang ada pada tabel, baik pada taraf signifikansi $5 \%(0,423)$ maupun pada taraf signifikansi $1 \%(0,537)$. Dengan demikian dapat disimpulkan bahwa ada korelasi signifikan antara motivasi belajar dengan prestasi belajar mata pelajaran PAI, sehingga hipotesa yang penulis ajukan dapat diterima.

\section{Saran}

Penelitian telah dilakukan, maka dari pengalaman hasil penelitian peneliti menawarkan beberapa saran :

1. Bagi pihak sekolah, penelitian ini dapat dijadikan acuan untuk lebih mengintensifkan hubungan yang sinergis antara sekolah dengan wali murid untuk membantu siswa dalam kegiatan belajar.

2. Bagi penelitian selanjutnya, mungkin ini bisa dijadikan bahan acuan dasar tentang penelitian pola asuh dan prestasi dan diharapkan penelitian selanjutnya bisa lebih fokus dan mendalam dari penelitian ini.

\section{Daftar Rujukan}

Aqib, Zainal. 2013, Model-model Media dan Strategi Pembelajaran Konstektual (inovatif). Bandung: Yrama Widya.

Arikunto, Suharsimi. 1999, Dasar-dasar Evaluasi Pendidikan. Jakarta: Bumi Aksara.

Arikunto, Suharsimi. 1998, Prosedur Penelitian Suatu Pendekatan Praktek. Jakarta: PT. Rineka Cipta.

Daradjat, Zakiah. 1995, Metodik Khusus Pengajaran Agama Islam. Jakarta: Bumi Aksara, Alfabeta.

Darmadi, Hamid. 2011, Metode Penelitian Pendidikan. Bandung:

Departemen Agama RI. 1989.Al Qur'an dan Terjemahnya, Surabaya : Mahkota Surabaya. 

Cipta.

Dimyati - Mujiono. 2013, Belajar dan Pembelajaran. Jakarta: Rineka

Hamalik, Oemar. 2010, Psikologi Belajar dan Mengajar. Bandung: Sinar Baru Algensindo.

Hariyadi, Moh. 2011, Statistik Pendidikan. Jakarta: Prestasi Purbakarya . Maret 2015.

http ://belajarpsikologi.com/pengertian-belajar-menurut-ahli/diakses tgl 14

Islamuddin, Haryu. 2012, Psikologi Belajar. Yokyakarta : Pustaka Pelajar,

Musfiqon. 2012. Panduan Lengkap Metodologi Penelitian Pendidikan. Jakarta: Prestasi Pustakarya.

Nasution. 1995, Didaktik Asas-asas Pengajar. Jakarta: Bumi Aksara.

Partanto, Pius A - M. Dahlan Al Barry, 1994, Kamus Ilmiah Populer. Surabaya: Arkola.

Permenag RI. No.2 Tahun 2008, SK-KD Pendidikan Agama Islam.

Sekaton, Rezky Amira. 2008, Kamus Populer Lengkap Bahasa Lndonesia.

Bogor: IndoBook Citra Media.

Slameto. 1988. Evaluasi Pendidikan. Jakarta: PT. Bina Aksara.

Subana, Moersetyo Rahadi, Sudrajat. 2000, Statistik Pendidikan. Bandung: CV. Pustaka Setia.

Sugiyono. 2011. Metode Penelitian Kuantitatif Kualitatif dan R\&D. Bandung: Alfabeta.

Suryabrata, Sumadi. 1984. Psikologi Pendidikan. Jakarta: CV. Rajawali.

Syah, Muhibbin. 2009, Psikologi Belajar. Jakarta: Rajawali Pers.

Trianto. 2011. Pengantar Penelitian Pendidikan Bagi Pengembangan Profesi Pendidikan dan Tenaga Kependidikan. Jakarta:Kencana.

Uno, Hamzah B. 2014. Teori Motivasi dan Pengukurannya. Jakarta: Bumi Aksara. 